\title{
Improved saccharification of steam-exploded Pinus radiata on supplementing crude extract of Penicillium sp.
}

\author{
Hamish Cameron • Sylke H. Campion • \\ Tripti Singh · Alankar A. Vaidya
}

Received: 12 February 2014/ Accepted: 21 March 2014/Published online: 6 April 2014

(c) The Author(s) 2014. This article is published with open access at Springerlink.com

\begin{abstract}
Commercially available enzymes do not contain all the necessary softwood-specific accessory enzymes to obtain high saccharification efficiency. In this work, six saprophytic fungi obtained from Pinus radiata plantation site were screened for the putative softwood-specific accessory enzyme, $\beta$-mannanase. A Penicillium sp. was found to produce $\beta$-mannanase in both solid (31.6 units/g of dry biomass) and liquid (117 units/g of dry biomass) cultures using locust bean gum as an inducer after 2 weeks of incubation. The saccharification of steam-exploded Pinus radiata was $7.8 \% \mathrm{w} / \mathrm{w}$ improved when the crude extract of Penicillium sp. was added to a mixture of commercial enzymes.
\end{abstract}

Keywords Accessory enzyme $\cdot$ Fungi $\cdot$ Hemicellulase · $\beta$-Mannanase $\cdot$ Saccharification $\cdot$ Softwood

\section{Introduction}

Woody biomass can be used as a feed-stock for the production of sugars which can be converted to biofuels and bio-chemicals (Zhu and Pan 2010). Enzymes can be used to break down wood into sugars but this is an expensive step

Electronic supplementary material The online version of this article (doi:10.1007/s13205-014-0212-2) contains supplementary material, which is available to authorized users.

\section{H. Cameron}

Faculty of Science and Engineering, University of Waikato,

Private Bag 3105, Hamilton, New Zealand

S. H. Campion - T. Singh · A. A. Vaidya $(\bowtie)$

Scion, Te Papa Tipu Innovation Park, Private Bag 3020,

Rotorua 3046, New Zealand

e-mail: Alankar.vaidya@scionresearch.com due to the cost of enzymes (Berlin et al. 2007). An alternative strategy is to decrease the cost of enzymes by producing a crude enzyme extract on-site, rather than using a commercial enzyme. Moreover, commercially available enzymes are limited in number and composition and have generally been optimized for non-woody herbaceous biomass (Banerjee et al. 2010; Berlin et al. 2007). In the case of herbaceous and hardwood plant species, the hemicellulose is xylan rich whereas for softwood it is mannan rich (Juturu and $\mathrm{Wu}$ 2013). In softwood, the presence of hemicellulose may limit the hydrolysis of cellulose in the absence of accessory enzymes (Várnai et al. 2011).

$\beta$-Mannanase (E.C. 3.2.1.78) is a key softwood-specific accessory enzyme as it cleaves the main chain of both glucomannans and galactoglucomannans (GGMs) into oligosaccharides (Várnai et al. 2011; Yang et al. 2009). Another strategy for obtaining a complete enzyme mixture involves blending crude enzyme extracts having softwoodspecific accessory enzyme with commercial enzymes. This approach has great potential since no activities are lost and it can lead to enzyme synergy and better saccharification efficiency (Yang et al. 2009).

In the screening of fungi for specific enzymes capable of degrading softwood biomass, it is crucial to search in the ecological niche where the desired biomass is growing. Hence, in this work, saprophytic fungi that grow in Pinus radiata plantations were selected (Visser et al. 2013; Singh et al. 2008; Zhang and Lynd 2004). Two fungi, each from the categories of brown rot, soft rot and mould were selected. The effect of solid versus liquid medium and incubation time on the extracellular production of $\beta$-mannanase from these six species was studied. For the first time, improvement in saccharification of steamexploded Pinus radiata substrate is demonstrated after supplementing commercial enzyme with crude enzyme preparation from New Zealand native Penicillium sp. 


\section{Materials and methods}

All fungi were obtained from Scion's mycological depository. The commercial enzymes Celluclast $1.5 \mathrm{~L}$ and Novo188 were obtained from Novozymes A/S. All other chemicals were purchased from Sigma-Aldrich and were used as received. An individual culture of each fungus was transferred from their glycerol stocks (40\% w/v glycerol) aseptically onto $1.5 \% \mathrm{w} / \mathrm{v}$ malt agar nutrient medium and incubated in the dark at $75 \%$ relative humidity and $25{ }^{\circ} \mathrm{C}$. Each fungus was grown for 2 weeks till mycelium and fungal colonies are clearly seen. These plates are used as the stock cultures in sub-culturing onto the fresh solid or liquid media.

Growth on solid medium

Malt agar $(0.5 \%$ w/v $)$ was prepared by dissolving $10 \mathrm{~g}$ of malt and $12 \mathrm{~g}$ of agar in $2 \mathrm{~L}$ deionized water with heating. While still liquid, it was divided equally into two $1 \mathrm{~L}$ flasks. One flask contained $5 \mathrm{~g}$ locust bean gum (LBG; $0.5 \% \mathrm{w} / \mathrm{v}$ ) and the other flask was kept as a control. The $\mathrm{pH}$ was adjusted to 5.0 using $0.4 \% \mathrm{HCl}$ or $0.5 \mathrm{M} \mathrm{NaOH}$ and both flasks were autoclaved at $121^{\circ} \mathrm{C}$ for $20 \mathrm{~min}$. The warm media were poured into pre-sterilized Petriplates $(40 \mathrm{~mL}$ per plate). The plates were allowed to cool to room temperature and then each plate was inoculated with $5-\mathrm{mm}$ diameter fungal plugs punched from stock culture plates. Duplicate plates were prepared for each fungus.

\section{Growth in liquid media}

Broth was prepared by dissolving, $\mathrm{KH}_{2} \mathrm{PO}_{4} 1 \mathrm{~g}, \mathrm{MgSO}_{4}$ $0.5 \mathrm{~g}$, ammonium tartrate $0.2 \mathrm{~g}, \mathrm{NaH}_{2} \mathrm{PO}_{4} 0.2 \mathrm{~g}, \mathrm{CaCl}_{2}$ $0.05 \mathrm{~g}, \mathrm{FeSO}_{4} 0.05 \mathrm{~g}, \mathrm{CuSO}_{4} 0.01 \mathrm{~g}, \mathrm{ZnSO}_{4} 0.005 \mathrm{~g}$, $\mathrm{MnSO}_{4} 0.005 \mathrm{~g}$ per litre of deionized water. Two litres of liquid medium was prepared and divided equally into two $1 \mathrm{~L}$ flasks. One flask contained $5 \mathrm{~g}$ locust bean gum (LBG; $0.5 \% \mathrm{w} / \mathrm{v}$ ) and the other flask was kept as control. In $100 \mathrm{~mL}$ capacity conical flasks, $40 \mathrm{~mL}$ of either control or locust bean gum (LBG) liquid medium was poured and flasks autoclaved at $121{ }^{\circ} \mathrm{C}$ for $20 \mathrm{~min}$ and then cooled to room temperature. Each flask was inoculated at room temperature using 5-mm diameter plugs punched from stock culture plates. Duplicate flasks were prepared for each fungus.

Fungal growth and crude enzyme recovery

The inoculated samples were incubated in the dark at $25{ }^{\circ} \mathrm{C}$ and at $75 \%$ relative humidity without shaking. At defined time intervals (7, 14, 21 and 28 days), duplicate samples of each fungus were removed and crude $\beta$-mannanase was recovered from solid medium as follows-at each time point, culture grown on solid medium was cut into $1 \times 1 \times 0.5 \mathrm{~cm}$ cubes and transferred into separate $50 \mathrm{~mL}$ capacity centrifuge (Falcon) tubes and crushed to fine particles. A $30 \mathrm{~mL}$ of $0.05 \mathrm{M} \mathrm{Na}$-citrate buffer (pH 5) was added and the mixture was incubated in a rotatory shaker at $15^{\circ} \mathrm{C}$ for $18 \mathrm{~h}$ at $220 \mathrm{rpm}$. Then, each sample was centrifuged at $10,000 \times g$ for $20 \mathrm{~min}$. The supernatant was decanted and the precipitate was washed once with $10 \mathrm{~mL}$ of $0.05 \mathrm{M}$ Na-citrate buffer $\mathrm{pH} 5$ and centrifuged at $10,000 \times g$ for $20 \mathrm{~min}$. The washing was mixed with the supernatant and kept in a refrigerator at $8{ }^{\circ} \mathrm{C}$ for further use. The solid mass precipitated was freeze dried and weighed. The weight of the dry biomass was calculated from the difference in dry weight of fungal culture grown on locust bean gum-solid medium and the control. Crude $\beta$-mannanase recovery from liquid medium - the contents from each flask were transferred to a $50 \mathrm{~mL}$ capacity centrifuge (Falcon) tube and centrifuged at $10,000 \times g$ for $20 \mathrm{~min}$. The supernatant was decanted and kept in a refrigerator at $8{ }^{\circ} \mathrm{C}$ for further use. The precipitated biomass was freeze dried and weighed.

\section{Enzyme assays}

$\beta$-Mannanase activity in the supernatant was measured using a partially depolymerized Carob-galactomannan conjugated with Remazol brilliant blue R (Megazyme, Ireland) as the substrate. The substrate stock solution was prepared at $1 \% \mathrm{w} / \mathrm{v}$ in $0.2 \mathrm{M}$ sodium acetate buffer $\mathrm{pH}$ 5.0. The substrate stock and crude enzyme supernatant were incubated separately at $40{ }^{\circ} \mathrm{C}$ for $3 \mathrm{~h}$ before the assay was performed. In $5 \mathrm{~mL}$ capacity glass tubes, $0.5 \mathrm{~mL}$ of stock substrate solution was mixed with $0.5 \mathrm{~mL}$ of crude enzyme solution and incubated at $40{ }^{\circ} \mathrm{C}$ for $2.5 \mathrm{~h}$. The reaction was terminated by the addition of $2.5 \mathrm{~mL}$ of ethanol $(95 \% \mathrm{v} / \mathrm{v})$. After brief vortexing, the absorbance of supernatant was measured at $590 \mathrm{~nm}$. Enzyme activity was determined from a standard calibration curve $\left(R^{2}=0.99\right)$ of Remazol brilliant blue R solution $(0.008-0.00016 \mu \mathrm{M})$ prepared in $0.2 \mathrm{M}$ sodium acetate buffer $\mathrm{pH}$ 5. One unit of $\beta$-mannanase activity was defined as the amount of enzyme which released $0.001 \mu \mathrm{M}$ of dye under assay conditions. Each assay was performed in quadruplicate and the average value is presented in Fig. 1. $\beta$-Glucosidase (E.C. 3.2.1.21) and $\beta$-mannosidase (E.C. 3.2.1.25) activity were each measured using $10 \mathrm{mM}$ of standard chromogenic substrates, i.e. $p$-nitrophenyl- $\beta$-D-glucoside and $p$-nitrophenyl$\beta$-D-mannoside, respectively (Bailey and Nevalainen 1981). One unit of activity was defined as the amount of enzyme which released $1 \mu \mathrm{M}$ of $p$-nitrophenol from their respective standard substrates under assay conditions. 
Fig. 1 a Crude $\beta$-mannanase recovery from solid medium. b Crude $\beta$-mannanase recovery from liquid medium. Data shown here are average of quadruplicate measurements with corresponding relative standard deviations. Filled triangles Penicillium sp., empty triangles Cladosporum herbarum, filled squares Oligoporus placenta, empty squares Lenzites trabea, filled diamonds Cephalosporium sp. and empty diamonds

Chaetomium globosum
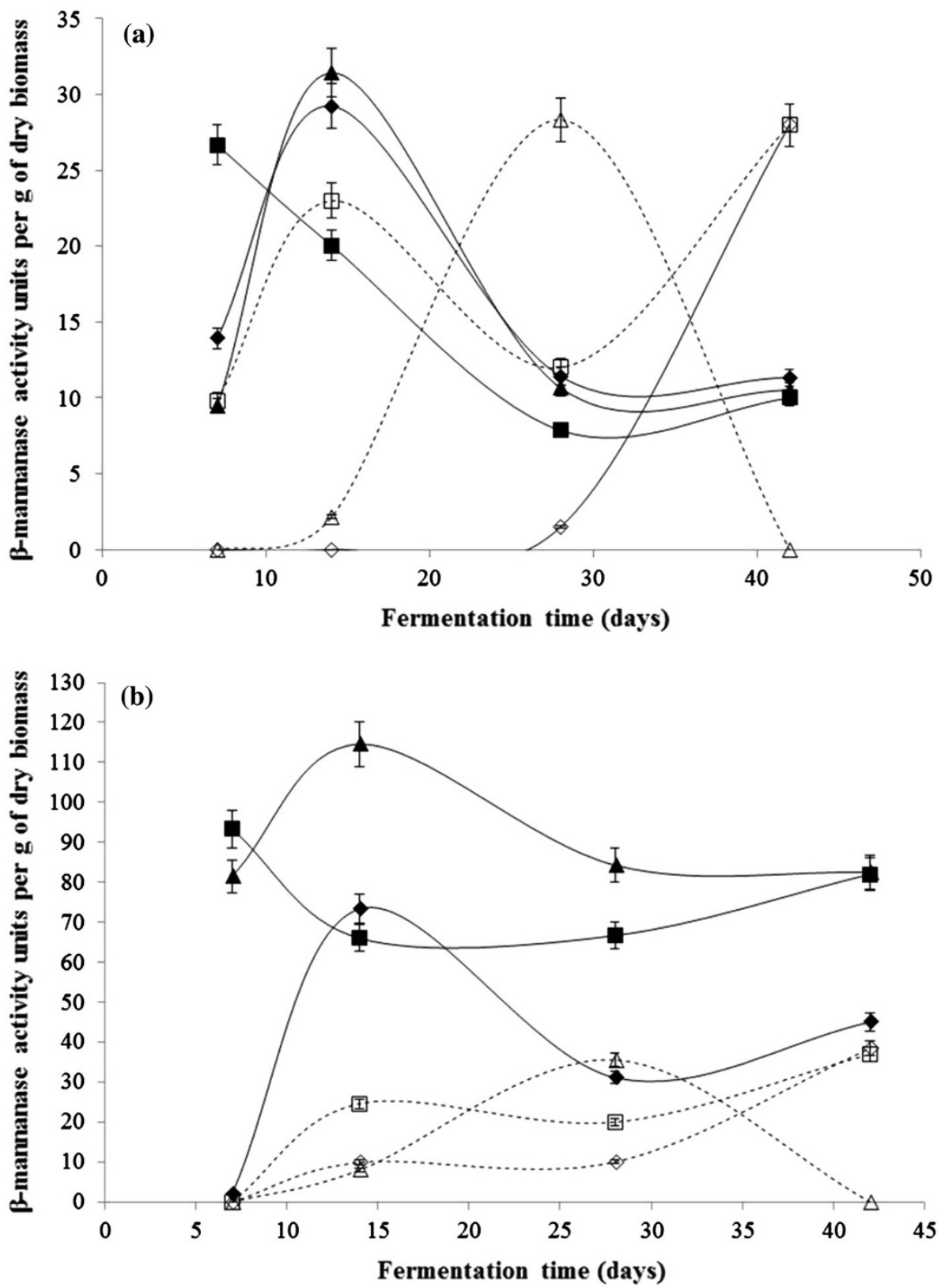

Enzymatic hydrolysis of steam exploded (SEW) Pinus radiata

SEW was produced in the steam explosion apparatus (Newman et al. 2013). $0.75 \mathrm{~kg}$ chips were taken with a moisture content of $60 \%$, impregnated with $\mathrm{SO}_{2}(3 \% \mathrm{w} / \mathrm{w})$ and heated with steam at $215^{\circ} \mathrm{C}$ for $3 \mathrm{~min}$. The SEW pulp was washed four times with water and oven dried at $110{ }^{\circ} \mathrm{C}$ to obtain a $54 \%$ yield. This substrate was hydrolysed using commercial enzyme in the form of Celluclast $1.5 \mathrm{~L}$ and Novo-188 at 10 FPU:12.5 CBU per g of substrate in a 5-mL saccharification mixture with and without addition of the freeze dried crude extract of Penicillium sp. at $100 \mathrm{mg} / \mathrm{mL}$. A control experiment was run in parallel in which hydrolysis of SEW was performed using only crude extract of Penicillium sp. at $100 \mathrm{mg} / \mathrm{mL}$ in $5-\mathrm{mL}$ mixture. All experiments were incubated at $180 \mathrm{rpm}$ agitation speed in an inclined vibratory shaker for $72 \mathrm{~h}$. Experiments were carried using a substrate concentration of $1.5 \%$ on a dry basis. The sugar composition (monomeric and oligomeric) of the saccharified filtrate was determined using ion chromatography as described elsewhere (Vaidya and Singh 2012).

\section{Results and discussion}

Cell growth for all six test fungi was normal when grown on control medium (without locust bean gum) but no 
$\beta$-mannanase activity was detected. This indicates that the presence of locust bean gum did not affect cell growth but did lead to extracellular secretion of enzymes required for the degradation of glucomannan. All fungi (except Cladosporum herbarum and Lenzites trabea) showed almost 200-400 \% higher $\beta$-mannanase activity units per $g$ of dry biomass when grown in liquid medium compared to solid medium (Fig. 1a, b). The improved enzyme production in liquid medium can be due to better accessibility of growing hyphae to locust bean gum.

Generally, the time profile of enzyme production is similar for a given fungi in solid and in liquid medium. An early induction period (7 days) was seen in the case of the brown rot Oligoporus placenta whereas Lenzites trabea only produced $\beta$-mannanase after a 14-day growth period and maximum activity occurred only after 42 days. Soft rot fungi had different induction responses to locust bean gum. Cephalosporium sp. produced the most activity at 14 days but then had an inconsistent response to locust bean gum, whereas Chaetomium globosum reached maximum production after 42 days. The two mould fungi Penicillium sp. and Cladosporum herbarum showed the highest $\beta$-mannanase activity at 14 and 28 days incubation period, respectively, and activity reduced thereafter.

Among six fungi tested, Penicillium sp. showed highest $\beta$-mannanase activity per $\mathrm{g}$ of dry biomass in both liquid and solid media. Moreover, it also showed low $\beta$-mannosidase activity (12.9 units) in accordance with the rare appearance of fungal $\beta$-mannosidase in the literature (Maijala et al. 2012; Valáŝkova and Baldrian 2006). Both $\beta$-mannanase and $\beta$-mannosidase activities are relevant to softwood glucomannan hydrolysis. Interestingly, none of the fungi expressed $\beta$-glucosidase activity either in liquid or solid medium.

Hydrolysis of SEW using Celluclast 1.5L:Novo-188 at 10 FPU:12.5 CBU per $\mathrm{g}$ of substrate gave $2.10 \pm 0.1 \mathrm{~g}$ of total glycosyl units (monomeric + oligomeric) per litre, which correspond to $26.1 \pm 1.3 \%$ w/w of polysaccharide conversion (Table 1). No mannosyl or galactosyl units were released from SEW using a mixture of commercial enzymes only. This is to be expected because the commercial enzyme preparation Celluclast $1.5 \mathrm{~L}$ contains $\alpha$-L-arabinofuranosidase, endo-xylanase and $\beta$-xylosidase suitable for degrading hardwood hemicellulose but lacks mannan-degrading enzymes, such as $\beta$-mannanase and/or $\beta$-mannosidase, which act as accessory enzymes in the hydrolysis of glucomannan and GGMs in softwood hemicellulose (Juturu and Wu 2013). When the commercial enzyme was supplemented with the crude enzyme preparation from Penicillium sp. the production of monomeric glucosyl units increased from $1.85 \pm 0.1$ to $2.48 \pm 0.1 \mathrm{~g} /$ L. This corresponds to a $7.8 \pm 0.4 \% \mathrm{w} / \mathrm{w}$ improvement in monomeric glucosyl released. This improvement in release of glucosyl units $(\mathrm{g} / \mathrm{L})$ during saccharification is due to the synergistic action of following enzymes-cellulase available from Celluclast 1.5L and crude extract of Penicillium sp. (for details refer to supplementary information), $\beta$ glucosidase available from Novo-188 and the presence of $\beta$-mannanase and $\beta$-mannosidase in the crude extract of Penicillium sp. Furthermore, from control experiment in which only crude extract of Penicillium sp. is used for SEW hydrolysis, a small amount of monomeric glucosyl units $(0.10 \mathrm{~g} / \mathrm{L})$ released because of lack of $\beta$-glucosidase activity in the crude extract. This in turn resulted in an accumulation of oligomeric glucosyl units $(0.41 \mathrm{~g} / \mathrm{L}$; $5 \% \mathrm{w} / \mathrm{w}$ cellulose conversion). Only in presence of crude extract of Penicillium sp., the conversion of soluble polymeric mannan to monomeric and oligomeric mannosyl units is achieved albeit the original hemicellulose content in SEW is small $(0.3 \% \mathrm{w} / \mathrm{w})$ (Table 1$)$. To corroborate this result further a comparison of crude extract of Penicillium sp. against commercial enzymes (both were taken on equal protein basis of $10 \mathrm{mg} / \mathrm{mL}$ ) in hydrolysis of locust bean gum $(1 \% \mathrm{w} / \mathrm{w})$ showed that using only crude extract twofold enhanced activity was obtained compared to commercial enzyme.

Thus, the crude preparation of Penicillium sp. has a boosting effect in the hydrolysis of pretreated softwood substrate and emphasizes the importance of a feedstock specific mixture of hemicellulase and cellulase enzymes (Gao et al. 2011). Várnai et al. (2011) reported a $4 \% \mathrm{w} / \mathrm{w}$ increase in the hydrolysis of steam pretreated spruce when

Table 1 Saccharification of SEW

\begin{tabular}{|c|c|c|c|c|c|c|}
\hline & \multicolumn{3}{|c|}{ Monomeric sugars $\mathrm{g} / \mathrm{L}$ (\% w/w conversion) } & \multicolumn{3}{|c|}{ Oligomeric sugars g/L (\% w/w conversion) } \\
\hline & Glucose & Mannose & Galactose & Glucosyl units & Mannosyl units & Galactosyl units \\
\hline Commercial enzyme & $1.85(23.0)^{\mathrm{a}}$ & 0.00 & 0.00 & $0.25(3.1)^{\mathrm{a}}$ & 0.00 & 0.00 \\
\hline Penicillium sp. crude extract (control) & $0.10(1.24)^{\mathrm{a}}$ & $0.01(33.3)^{\mathrm{a}}$ & 0.00 & $0.41(5.08)^{\mathrm{a}}$ & $0.02(66.7)^{\mathrm{a}}$ & $0.01(66.7)^{\mathrm{a}}$ \\
\hline Commercial enzyme + Penicillium sp. extract & $2.48(30.8)^{\mathrm{a}}$ & $0.01(33.3)^{\mathrm{a}}$ & 0.00 & 0.00 & $0.02(66.7)^{\mathrm{a}}$ & $0.01(66.7)^{\mathrm{a}}$ \\
\hline
\end{tabular}

All values in the table are the mean of triplicate experiments and have a standard deviation of $\pm 5 \%$. The sugar composition (\% w/w) of original SEW is-glucosyl units $=53.6$; mannosyl units $=0.3$; galactosyl units $=0.1$

${ }^{a}$ The numbers shown in the parentheses are $\%$ w/w conversion of sugars from the original SEW sample taken in $5 \mathrm{~mL}$ saccharification 
Trichoderma reesei $\beta$-mannanase supplemented at 1:4 w/w on protein basis with cellulases mixture (Várnai et al. 2011). This work indicates that the effectiveness of a mixture of commercial cellulases can be improved by adding biomass-specific accessory enzymes and, therefore, has commercial implications in the production of biofuel enzymes. Additional work on enzyme purification and improving production of $\beta$-mannanase by whole genome mutagenesis of Penicillium sp. or heterologous expression of the $\beta$-mannanase gene into Pichia pastoris are a subject matter of future communication.

Acknowledgments This work was financially supported by the Scion core funding in Bioenergy. The authors wish to thank Daniel van de Pas for SEW preparation and Katrina Martin for analysis of the substrate using ion chromatography. The help offered by Dr. Ruth Falshaw and Dr. Ian Suckling in proof reading this manuscript is also acknowledged.

Conflict of interest The authors declare that they have no conflict of interests in this research paper.

Open Access This article is distributed under the terms of the Creative Commons Attribution License which permits any use, distribution, and reproduction in any medium, provided the original author(s) and the source are credited.

\section{References}

Bailey MJ, Nevalainen KMH (1981) Induction, isolation and testing of stable Trichoderma reesei mutants with improved production of solubilizing cellulase. Enzyme Microb Technol 3:153-157

Banerjee G, Scott-Craig JS, Walton JD (2010) Improving enzymes for biomass conversion: a basic research perspective. Bioenergy Res 3:82-92

Berlin A, Maximenko V, Gilkes N, Saddler J (2007) Optimization of enzyme complexes for lignocellulose hydrolysis. Biotechnol Bioeng 97:287-296
Gao D, Uppugundla N, Chundawat S, Yu X, Hermanson S, Gowda K, Brumm P, Mead D, Balan V, Dale BE (2011) Hemicellulases and auxiliary enzymes for improved conversion of lignocellulosic biomass to monosaccharides. Biotechnol Biofuels 4:5. doi:10. $1186 / 1754-6834-4-5$

Juturu V, Wu JC (2013) Insight into microbial hemicellulases other than xylanases: a review. J Chem Technol Biotechnol 88:353-363

Maijala P, Kango N, Szijarto N, Viikari L (2012) Characterization of hemicellulases from thermophilic fungi. Antonie Van Leeuwenhoek 101:905-917

Newman RH, Vaidya AA, Campion SH (2013) A mathematical model for the inhibitory effects of lignin in enzymatic hydrolysis of lignocellulosics. Bioresour Technol 130:757-762

Singh T, Vesentini D, Singh AP, Daniel G (2008) Effect of chitosan on physiological, morphological and ultrastructural characteristics of wood degrading fungi. Int Biodeterior Biodegrad 62:116-124

Vaidya A, Singh T (2012) Pre-treatment of Pinus radiata substrates by basidiomycetes fungi to enhance enzymatic hydrolysis. Biotechnol Lett 34:1263-1267

Valáŝkova V, Baldrian P (2006) Degradation of cellulose and hemicelluloses by the brown rot fungus Piptoporus betulinusproduction of extracellular enzymes and characterization of the major cellulases. Microbiology 152:3613-3622

Várnai A, Huikko L, Pere J, Siika-aho M, Viikari L (2011) Synergistic action of xylanase and mannanase improves the total hydrolysis of softwood. Bioresour Technol 102:9096-9104

Visser EM, Falkoski DL, de Almeida MN, Maitan-Alfenas GP, Rezende ST, Guimarães VM (2013) Production and application of an enzyme blend from Chrysoporthe cubensis and Penicillium pinophilum with potential for hydrolysis of sugarcane bagasse. Bioresour Technol 144:587-594

Yang X, Jiang Z, Song H, Jiang S, Madzak C, Ma L (2009) Cellsurface display of the active mannanase in Yarrowia lipolytica with a novel surface-display system. Biotechnol Appl Biochem 54:171-176

Zhang YHP, Lynd LR (2004) Toward an aggregated understanding of enzymatic hydrolysis of cellulose: noncomplexed cellulase systems. Biotechnol Bioeng 88:797-824

Zhu JY, Pan XJ (2010) Woody biomass pretreatment for cellulosic ethanol production: technology and energy consumption evaluation. Bioresour Technol 101:4992-5002 